\title{
KȘEMENDRA の韻律論
}

\section{Suvrttatilaka に見られる詩型提示の特殊技巧}

\section{小林 明 美}

Kșemendra は11世紀中葉カシミールの詩人であり，その多作ぶりと特異な作 風でサンスクリット交學史にニニークな地位を占めるてとは周知の通りである。 現存する作品18は，次の三部類に大別されよう。

第一は，古くから傳わる大作の梗概を，彼自身の kāvya 體で要約，紹介する， いわゆる kathāsāra 形式のもので, 有名な三部作 Rāmãyanamañjarī, Brhatkathāmañjarī, Bhāratamañjarī の外, Avadānakalpalatā は，佛敉說話文學を 素材とした稀な正統 kāvya 作品として注目される。

第二は，インド交學央上に稀有のモラリストとして，Kșemendra の名を特に 高める一連の nīti-kāvya（處世䍩訓詩）であるが，中でも，Samayamātrkāa(契約 による母) すなわち『遊女屋の女將』と題する遊女敉育の指南書とも稱すべき作 品は, カシミールの先人 Dāmodaragupta の作 Kuțtanimata『遣手婆の意見』 と共に奇書とされている。

第三の部類には，kavi-śikṣā（詩作者の手引）とも命名さるべき三作品が現存す る。その內, Kavikaṇthābharaṇa と Aucityavicäracarcā は, サンスクリット 詩學 (alamināra-śāstra) の發展史上でその意義を認められる作品ではあるが，例 えば Mammața の Kāvyaprakāás に見られるように，詩學ないし修辭學の全論 點にわたる體系的敍述として意圖されたものではない。同樣に，殘る一作品，以

ChS=Pingala : Chandaḥsūtra, KM 91, Bombay 1908.

NŚ=Bhārata : Nāṭyaśāstra, (Vol. II) GOS LXVIII, Baroda 1934.

SVT=Kșemendra : Suvṛttatilaka, Kṣemendralaghukāvyasamigraha, II. 3, Hyderabad 1961.

VR=Kedārabhațța : Vṛttaratnākara, NSP, Bombay 1908. 
下に取り上げる Suvrttatilaka も， chandas（韻律論）という śāstra が傳統的に 取り扱う項目を網羅したものでは決してないのである。

Suvrttatilaka は, 三つの章 vinyāsa から成る。後の二章は, 他の chandas テクストに類例を見ぬものであり，すなわち，第二章 guna-doṣa-darśana は，個 々の音ないし交字が與光る感じと詩文の基調をなする情趣 rasa との關係を論じ て，むしろ，alamikāra-śāstra における guna/doșa 論と觸れ合う面が大きいよ らに思われる。また第三章は，過去の知名な詩人が，圭として愛好した韻律を列 擧しており，多少とも共通の趣きをもつ書として，Rājaśekhara の Kãvyamĩ$m \bar{a} \dot{m} s \bar{a}$ が考光得る唯一のものであろう。

さて，殘る第一章においても，終始 metre の圖式が较示されていながら，『韻 律の美を考虑し saundaryam vicārya，kāvya 詩作に適するととが世に自明と される韻律 prasiddha-kāvyakarmanya-vṛtta のみを集錄し，もって門下俊秀の 文才に仕上げをかけるとと suśiṣyāṇām sarasvatyāh prasādhanam』を意圖 するが故に，他の chandas テクスト一般のように， metre の全てが記述の對象 となることはない。てのようにして取り上げられる韻律は27種，それも書名 $S u$ vrttatilaka の示すように, vṛtta すなわち akșaracchandas（各行の音篩數と各音 節の長短とが規定される metre)のみであって, āryā を代表とする mātrāchandas あるいは jāti（各行の mora の總數が規定される metre）は排除されている。同樣 に，chandas テクストが好んで取り上げる yati (caesura 位置) 指定は，ててで は見られない。

chandas (韻律論) は，言うまでもなく，vedānnga（ヴェーダ補助學） 6 種の一 つに數えられ，したがって，Rși Pingala の作とされる (Paingala) Chandahsūtra は，一見, vedānnga としての sūtra の地位を主張する如くではあるが，現 存する形では, ヴェーダ韻律よりも, より大きな比率で, 古典サンスクリット metre を，その記述の對象とし，制作年代は，精ヶ，西紀紀元前後あたりにしか 遡り得ないであろう。しかしながら, chandas の起源が, 演劇論 nāṭaka-lakșana， 詩論 alamkāra-śāstra のそれよりは, 古いことに疑いはなく, 詩論, 演劇論共 通の源泉である（Bhāratĩya） Nātyaśāstra，第十五章韻律論が，Paingala

(1) SVT, I. 5 
Chandahsütra を先立していたであろらといらのが定說となっている。ただし， 以後, chandas は古典期 śāstra としてさほど大きな地位を占めることはなく， 標準的な manual とされる Kedārabhațța の Vrttaratnakara は，14世紀， Gañgādāsa の Chandomañjarī は，12世紀以降というように，Kṣemendra の Suvrttatilaka よりも後期の作である。

Pingala 以来, サンスクリット韻律論で, 8 種の gana (ya, ra, ta, bha, ja, sa, ma, na) と長・短音節の略號 la, ga（laghu, guru）を略號體系として用いるこ とは, Sanskrit Prosody にも見られる通りである。てれらの gana は，古典の 韻律における bacchius, dactyl 等のように，Rythmik の單位をなすものでは なく, 單に詩型を記憶する Mnemotechnik の便法である。すなわち, との gana

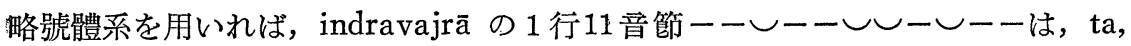
ta, ga, ga と圖式化され得る。

ところで, indravajrā のI 行が,てのよらな構成であるべき旨を敉えるVrttaratnäkara の定句 lakșaṇa は次の通りである。

syād indravajrā yadi tau jagau gah ${ }^{(3)}$

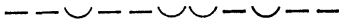

『もし，二つの ta (“tau”; dual), ja と ga (“jagau”; dvandva, dual) そして 一つの ga ("gaḥ”; sg.) とあるならば, その metre は, indravajrā である。】

これは型態上 indravajrā の構成をとっていると同時に, その意味内容は indravajrā 定義である。ことに，第一の技巧が見られるのである。さらに，Vrttaratnākara は, 次のような indravajrā による完全な一スタンザを, 例 udāharaṇa として揭げている。

satpāțavān pakṣavilopadakṣā lakṣmịh karoti prativādimukhyān /

mānātirūụhā tava durnivārā vāg indravajrāsir ivācalendrān ${ }^{(6)} / /$

四行目の “indravajrāsir” には, 問題の metre 名 indravajrā の語形自體が よみ込まれている。てれが第二の技巧である。

(2) Apte, V. S.: Sanskrit English Dictionary, Appendix 1.

(3) VR, III. 3

(4) sic! “-dakṣăl”” と䚾むべきである。

（5） sic! “lakṣyī-karoti”と讀むべきである。

(6) VR, udāharaṇa ad loc. 
さて, Vrttaratnakaraに見られる二種類の技巧のらち, 後者, すなわち, 例 詩中に metre 名を盛り込む技巧は, Națaśastra について見ると次の通りであ る。

tvam durṇirīkṣyā duratiprasădā duḥkhaikasādhyā kaṭhinaikabhāvā / sarvāsvavasthāsu ca kāmatantre yogyāsi kim vā bahunendravajrā // ${ }^{(7)}$ との indravajrā に對する Nătyaśāstra の例詩では, 第四行スタンザ未に “indravajrā”語形がよまれている。

他方, Pingala の Chandahsutra に對する Halāyudha (10世紀?) の手になる 次の泩釋も，同樣の技巧を備えた例詩を示す。

ye dușțadaityā iha bhūmiloke dveșam vyadhur godvijadevasamghe/

tān indravajrāad api dāruṇāñgān vyājīvayad yah satatam namas tel/

第三行に “indravajrād” とある。とのように一貫性のある特徵を指摘し得る ことから, Halāyudha 泩釋の源流をなしたと思われる口頭泩釋が，すでにての 種の例詩の技巧を實現していたとも推測される。

ところが, udāharaṇa に先立つ lakṣaṇa 面では, すなわち, 詩型構成を表示 する樣式ではどらであろらか。Pingala と Nātyaśāstra では對照的な相違があ る。Pingala は, sūtra として當然壓縮表現を狙うのであるから, gaṇa の略號 を用いて,

indravajrā tau jgau $\stackrel{(9)}{g} /$

と打出す。てれは，完全な技術的定式であって，韻文をなさず，したがって何ら の metre をも構成していない。逆に, Nätyaśāstraは, lakșaṇa において gana 略號を用いるととなく，次のように， śloka（anușțubh）の完全一スタンザで與 える。

navamam saptamam ṣaștham tṛtīyam ca bhavel laghu / ekādaśākșare pāda indravajreti sā yathā / $^{(10)}$

『11音節の 1 行において, 第九, 第七, 第六, 第三音節が短（ということは, 殘餘が長) の場合, metre は indravajrā である。例えば, 次の詩のでとし。』 そこで, Vrttaratnākara の lakșaṇa に立ち戻って見れば, gaṇa 略號を使用

(7). NŚ, XV. 43

(8) Halāyudha : Mṛtasamijīvanī ad ChS, VI. 15

(9) ChS, VI. 15

(10) NŚ, XV. 42 
する點では, Pingala に, lakṣaṇa 定句が韻文といら點では, Näṭyaśāstra に一 致し,しかも, その韻文が, 問題の metre による一行をなすといら點が, Vrttaratnākara 獨自の高度な技巧といらととになろら。

ここで, Kșemendra の Suvrttatilaka 第一章における詩型表出の仕方を，同 しく indravajrā について見ると, lakṣaṇa は次のよらに述へられる。

takārābhyām jakāreṇa yuktam guruyugeṇa ca /

indravajrābhidam prähur vṛttam ekādaśākșaram (11)

『二つの ta の字，一つの ja 字，そして一對の guru（長音節）を備えた11音 節の metre を世人は indravajrā なる名をもって呼ぶ。』

Pingala gaṇa 略號を用い，しかも韻文の lakṣaṇa と言えば，Vrttaratnākara と同樣であるが，その韻文が śloka の一スタンザである點は，Nātyaśästra 軌を一にする。このよらに，詩型提示 lakșaṇa の面での技巧といら限り， indravajrā の lakṣaṇa を indravajrā なる metre 自體の 1 行で呚えるVrttaratnakara の方が明らかに，一層巧度は高いと言わねばなるまい。

ところが，續く例詩では，Kșemendra は，他の書には見られぬほとんど曲㙯 じみた技巧を試みているのである。すなわち，

tau janmagūḍhau caraṇena yasya kaṣṭau nivișțau hṛdi kāmakopau /

tam duhsahās tā jvaladindravajrapātopamāḥ kleśadaśā viśanti //

の indravajrā 詩節において, indravajrā の名がよみ込まれる（第三行末 “jvaladindravajra-”)。そとまでは Vrttaratnäkara と同樣，つまり，Nātyaśāstra 以 來の技巧に外ならない。ととろが，その外に，例詩の冒頭に“tau”とあるのを gaṇa 略號 ta の dual, すなわち, 『二つの ta』と解し, 續いて “janma-”の ja をとり，續く子音結合を含む音節 nma をとばして，“-gūḍhau”の gū は，guru の略稱 gu の dual, すなわち『二つの guru』ととれよら。つまり, Kșemendra 獨自の技巧として, 例詩の初頭に列なる音節から, 問題の metre の略號スキー ム(こてでは, indravajrā の ta, ta, ja, ga, ga) が何とかして, 示晙され得るよら に配慮されているわけである。

こらいった極度の技巧が果して實現可能なものであろらか。實は, 上述の “tau

(11) SVT, I. 18

(12) op. cit., udāharaṇa ad loc. 
janmagũụhau” の場合でも，第二音節 nma は共に gaṇa 略號としてあるにも 拘らずとばさねばならなかった。今，17音節の metre, narkuțā の場合を見てみ よう。 na, ja, bha, ja, ja, la, ga，の構成に對して，例詩第一 pāda は， nijabhujajair viśālagunavikramakīrtibharaiḥ.

とあり，初頭より，子音結合 $\mathrm{rv}$ を含む第五音節 $\mathrm{rvi}$ をばし，また，gana 略 號をなさぬ śa に基づく第六音節 śā をとばすと，子昔は正に， n, j, bh, j, j, l, $\mathrm{g}$ ，と續いて，スキームと完璧に一致する。それでは，以上の二例から，「例詩內 で，二重子音は詩型示唆の價値を持たない」といった原則が引き出されるのであ ろらか。11音節 śâlinī (ma, ta, ta, ga, ga) のスキームについて見ると, Kṣemendra の例詩の第一 pãda は,

mattā goșthī garbhamū d̦hapralāpāa

であるが，第四音節の ș および țh は gaṇa 名稱をなさぬからとばし得るが， 第二音節の子音結合 $\mathrm{tt}$ はどらしてもスキームを示唆する要素として，二つの $\mathrm{t}$ 亿 とらねばならない。そらして初めて，上記のスキームが得られるのである。

例詩における子音結合に詩型示唆の價値を認めるかどらか。ての點においてさ え,すでに Kșemendra の一貫性の缺如が明らかであるが,しかも, 上述の indravajrā, narkuṭā, śālinī の三つの場合は，それでも，Kṣemendra が意圖した技 巧に最も成巧した事例なのである。1 行 11 音節の indravajrā から 21 音節の sragdharā まで Kṣemendra は, kāvya の metre 20 種を取り上げているが, 例詩におけるこの技巧の成功度は非常に低い, 平均值を窺ら一例として, vasantatilaka の場合を見ると， 1 行 14 音節，ta，bha，ja，ja，ga，ga の圖式を，例詩 の第一 pāda

tadbhāji janmasacive bhagavaty anange

の初頭より捉えようとする時, 第二音節の子音結合から後の bh を加えると, $t$, $\mathrm{bh}, \mathrm{j}, \mathrm{j}$ までは無事連續して得られるが，殘る ga 二つを得るためには，ずっと 後の “bhaga-”のg と，“anange” の子音結合をなしてある g とをとる外ない。 そこまでには, “janma-”の n, m, “-sacive” の s, “bhaga-”の bh, さらに, 二つの $\mathrm{g}$ の間にも，子音結合 ty の夫ネ, “anange”の $\mathrm{n}$ といった gana 名稱を なす子音の數多くを無視しなければならない。これでは，例詩の初頭より，ta，

(13) op. cit., udāharaṇa ad I. 22

(14) op. cit., I. 22

(15) op. cit., udāharaṇa ad I. 29 
bha, ja, ja，ga，ga の圖式を豫想せよといら作者の意圖は，全く無理である。

結局, Kșemendra は，曲藝的技巧を狙って結果は完全に失敗とななったので あるが，しかも，その失敗を最もよく意識していたのは，當の Kṣemendra 自身 であったと信ずべき節がある，というのは，詩型提示に入るに先立ち，彼が揭げ る文意不分明なスタンザ I. 9 が，實は，その失敗に對して豫めされる苦しい辯 明に外ならぬかと思われる。

kvacid vikṣiptasaminthānaị kvacid ekapadasthitaị /

saminogasthaiḥ kvacid dattam udāharaṇam akṣaraị̣ //

『ある場合には，散在する vikṣipta-samisthāna 一連の音，ある場合には，一個 所に集った ekapada-stha 一連の音, ある場合には, 子音結合をなしている samyoga-stha 一連の音によって, 例詩は擧げられる。』

第一，第二の kvacit の内容, vikșipta-samsthāna と ekapada-stha とは, 相對立する性質であり，第三の kvacit 內容, samyoga-sthaは，てれに對立する ものとして, *a-samyoga-stha を示唆する。つまり, Kșemendra が, 本來志し たのは, ekapada-stha (一箇所に集ってあり)しかも，*a-samyoga-stha（子音結合 をなさない) 音群で問題の metre 圖式が示されるようにするてとであった。しか るに意志と反し，ての二つの原則が，いずれも守れない結果となった。この失敗 を意識し，豫めその點の非難を防止すべく，第一，第三の kvacit, “kvacid vikṣipta-samisthānaih’, “kvacit samyoga-sthaih" と拔目なく先手打つてぼかし ている，といらのが眞意であろう。

(16) op. cit., I. 9 